\title{
Genetic variability among and within races of Heterodera glycines Ichinohe assessed by RAPD markers*
}

\author{
Adailton T. da Silva ${ }^{1}$, Júlio C.V. Penna ${ }^{2}$, Luiz R. Goulart ${ }^{3}$, Maria A. dos Santos ${ }^{2}$ and Neylson E. Arantes ${ }^{4}$
}

\begin{abstract}
Heterodera glycines Ichinohe, the soybean cyst nematode (SCN) was detected in Brazil in 1992 and since then it has been causing losses to Brazilian soybean crop yields. SCN populations have great genetic diversity which makes it difficult to manage this disease. The objectives of this research were to investigate the genetic variation of $16 \mathrm{SCN}$ populations sampled in middle western and southeastern Brazil, utilizing random amplified polymorphic DNA (RAPD) techniques, and to establish useful and specific RAPD markers for SCN race 3. RAPD markers demonstrated genetic variability among and within SCN populations, and they could be used for monitoring nematode population dynamics. The OPA-07 primer was a reliable molecular marker for race 3, while electrophoretic profile analysis of DNA fragments amplified with OPA-10 primer detected slight variation within those populations identified as race 3 . The SCN population from Chapadão do Céu, GO - sample 2 - was the most genetically distant from the other populations.
\end{abstract}

\section{INTRODUCTION}

Soybean, Glycine max (L) Merrill, is a crop of paramount importance in Brazil, which is the second leading producer of this crop in the world. The country produced about 23 million tons of soybeans on 10 million hectares in 1996 (EMBRAPA, 1996).

Heterodera glycines Ichinohe, the soybean cyst nematode ( $\mathrm{SCN}$ ), is today the most important pathogen of the crop in the United States and eastern Asia (Baldwin and Mundo-Ocampo, 1991; Anand et al., 1994). During the 1991/1992 Brazilian growing season, this nematode was found for the first time in the States of Goiás, Mato Grosso, Mato Grosso do Sul and Minas Gerais (Mendes and Dickson, 1993).

Populations of SCN normally have great genetic diversity, which can be determined by their ability in reproducing on selected soybean genotypes (differential hosts) (proposed by Golden et al. (1970) and expanded by Riggs and Schmitt (1988)). Aiba et al. (1995), for example, demonstrated genetic variability within and among populations of $H$. glycines based on soybean differentials. Although several biochemical techniques have been attempted for race identification of this nematode, they have not been useful (Griffith et al., 1982; Pozdol and Noel, 1984). However, analysis of DNA polymorphisms, either as random amplified polymorphic DNA (RAPD) (Vasconcelos et al., 1994) or restriction fragment length polymorphisms (RFLP) (Kalinski and Huettel, 1988), have been successfully used.
Plant-parasitic nematode genomic DNA has been investigated primarily through RFLP, which can differentiate species and, in some cases, races and populations of nematodes (Curran et al., 1986; Kalinski and Huettel, 1988). Nevertheless, the RFLP technique has some limitations, such as the requirement for a large amount of DNA, high labor input, use of radioisotopes, and lack of sufficient sensitivity to distinguish races (Curran et al., 1986; Kalinski and Huettel, 1988; Castagnone-Sereno, 1992).

DNA polymorphism assays based on polymerase chain reaction (PCR) amplifications of DNA segments using single primers of arbitrary nucleotide sequence (RAPD) analysis (Welsh and Mcclelland, 1990; Williams et al., 1990) have been used for genetic markers in a variety of plants (Demeke et al., 1992; Mackill, 1995; Orozco-Castilho et al., 1996), fungi (Assigbetse et al., 1994; Woo et al., 1996) and nematodes (Caswell-Chen et al., 1992; Folkertsma et al., 1994; Guirao et al., 1995). The ability of RAPD markers to detect genetic variation among cyst nematodes was reported by CaswellChen et al. (1992), Folkertsma et al. (1994), and Vasconcelos et al. (1994).

This research has the objectives of evaluating the application of RAPD analysis to assess genetic variability among $16 \mathrm{H}$. glycines populations from several locations in Brazil, establishing useful RAPD markers specific for race 3 , and determining variation within populations of race 3 (through differential genotypes) of this nematode.

*Part of a thesis presented by A.T.S. to the Universidade Federal de Uberlândia (UFU) in partial fulfillment of the requirements for the Master's degree. ${ }^{\prime}$ Ministério da Agricultura, Delegacia Federal de Agricultura de Minas Gerais, Representação Regional de Uberlândia, Caixa Postal 590, $38400-156$ Uberlândia, MG, Brasil. Send correspondence to A.T.S. Fax: +55-34-235-8014. E-mail: adatom@ uol.com.br 


\section{MATERIAL AND METHODS}

\author{
Genetic material
}

Sixteen SCN populations from Brazil were used, 10 of which were collected in several sites in Minas Gerais State (Table I). Nine of the populations had their corresponding races previously determined. Therefore, populations from Coromandel, Monte Carmelo, Pedrinópolis, Santa Juliana, Uberaba and Uberlândia were characterized as composed of race 3 (Silva, 1997), while the ones from Primavera do Leste (MT), Campo Verde (MT) and Água Clara (MS) were obtained at Empresa Brasileira de Pesquisa Agropecuária/Centro Nacional de Pesquisa de Soja (EMBRAPA/ CNPSo - Londrina, PR) and identified as races 1, 2 and 9, respectively. The remaining SCN populations have not been identified as to their race constitution.

\section{Cyst and egg extraction}

Two hundred viable cysts were extracted from each population using the centrifugal-flotation method, with slight modifications (Jenkins, 1964, cited by Mendes, 1986). After extraction, cysts were placed into $1.5-\mathrm{ml}$ Eppendorf tubes and stored at $-80^{\circ} \mathrm{C}$. Females and cysts were treated with $0.5 \%$ sodium hypochloride for one minute before extraction, following crushing on a 100mesh sieve. Eggs and second-stage juveniles were washed and collected on a 500-mesh sieve, then placed in 1.5-ml Eppendorf tubes and centrifuged at 3,000 rpm (about 650 $g$ ) for five minutes. The remaining $100 \mathrm{ml}$ suspension of eggs and juveniles was stored in a refrigerator until DNA extraction.

\section{DNA extraction}

Eggs and juveniles were powdered in liquid nitrogen in 1.5-ml Eppendorf tubes and $700 \mu \mathrm{l}$ of extraction buffer (2\% CTAB, 1.4 M NaCl, 100 mM Tris-HCl, pH 8.0, 20 mM EDTA and $1 \% \beta$-mercaptoethanol added at the time of utilization) was added. The homogenate was incubated in a water bath for two hours at $65^{\circ} \mathrm{C}$, cooled on ice, and spun at $1,000 \mathrm{rpm}$ for one minute at $4^{\circ} \mathrm{C}$ in a microcentrifuge. The supernatant was transferred to a new tube and an equal volume of chloroform + isoamyl alcohol (24:1) added and extracted twice. After centrifugation at 13,000 rpm (about 12,000 $\mathrm{g}$ ) for $15 \mathrm{~min}$, approximately $500 \mu \mathrm{l}$ of the aqueous phase was transferred to a new tube, and DNA was precipitated by adding 2 volumes of isopropanol. The suspension was maintained at $4^{\circ} \mathrm{C}$ overnight. After a new centrifugation at 13,000 rpm for $10 \mathrm{~min}$, the supernatant was discarded, and the precipitate was rinsed once with $500 \mu \mathrm{l}$ of $70 \%$ ethanol, air dried for two hours, and resuspended in $100 \mu \mathrm{l}$ TE buffer $(10 \mathrm{mM}$ Tris, $0.1 \mathrm{mM}$ EDTA, pH 8.0) plus $40 \mu \mathrm{g} / \mathrm{ml}$ of RNAase. The solution was maintained at $37^{\circ} \mathrm{C}$ for $30 \mathrm{~min}$ and incubated in a wa- ter bath for $20 \mathrm{~min}$ at $60^{\circ} \mathrm{C}$. Nucleic acid concentration was determined spectrophotometrically at $260 \mathrm{~nm}$ (Sambrook et al., 1989).

\section{DNA amplification}

DNA amplification reactions were performed in a thermocycler and consisted of 45 cycles, each consisting of the following steps: denaturation $\left(94^{\circ} \mathrm{C}\right.$ for $\left.1 \mathrm{~min}\right)$, annealing $\left(34^{\circ} \mathrm{C}\right.$ for $\left.1 \mathrm{~min}\right)$, and elongation $\left(72^{\circ} \mathrm{C}\right.$ for $\left.2 \mathrm{~min}\right)$. Each reaction mixture $(25 \mu \mathrm{l})$ contained: $10 \mathrm{mM}$ Tris- $\mathrm{HCl}$, pH 8.0, $50 \mathrm{mM} \mathrm{KCl}, 2.5 \mathrm{mM} \mathrm{MgCl} 2,100 \mu \mathrm{M}$ of each deoxyribonucleoside triphosphate (dATP, dTTP, dCTP, and dGTP), 1.5 units of Taq DNA polymerase, $20 \mathrm{ng}$ of genomic DNA, and $0.4 \mu \mathrm{M}$ of a single primer (Operon Technologies, Inc.; Table II). Control reactions, containing all components except template DNA, were included to avoid misinterpretations of RAPD patterns due to PCR artifacts. Samples were overlaid with mineral oil to prevent evaporation. After amplification, DNA products were separated electrophoretically on $8 \%$ polyacrylamide gels prepared according to Sambrook et al. (1989) in TBE buffer 1X (0.09 M Tris-borate, and 2 mM EDTA). The " $1-k b$ DNA ladder" was used as the molecular weight standard. Gels were stained with ethidium bromide $(0.5 \mu \mathrm{g} / \mathrm{ml})$ and photographed with polaroid 667 film under ultraviolet light.

Data analysis

DNA bands were scored as 1 (presence) or 0 (absence). Only intense and reproducible bands were considered. These data were used to determine the pairwise genetic distances among the SCN populations using percent disagreement (PD) (Skroch et al., 1992). Dendrograms were constructed from these PD values using the unweighted pair group method with arithmetic mean (UPGMA).

\section{RESULTS}

The 12 primers (Table II) resolved 68 different DNA fragments. The number of fragments produced per primer varied from two to eight and ranged in size from 0.38 to $5.40 \mathrm{~kb}$.

The genetic distance matrix, based on band presence versus absence, was estimated as percent disagreement (Table III). The shortest distance was $1 \%$, found between some of the SCN populations from Minas Gerais State. These results are in accordance with reports that characterize all soybean cyst nematode populations from Minas Gerais as race 3 (Arantes et al., 1994; Noel et al., 1994; Rossi et al., 1994; Wain and Silva, 1996; Silva, 1997). The greatest distance was found between $\mathrm{SCN}$ populations from Chapadão do Céu, GO, and Iraí de Minas, MG (Table III).

A dendrogram was constructed, representing the relationships among the 16 populations of the nematode 
(Figure 1). There were large divergences among these populations. The SCN populations from Uberlândia and Pedrinópolis were quite similar and were clustered together, followed by populations from Uberaba, Monte Carmelo, Iraí de Minas (sample 1), Iraí de Minas (sample 2), Coromandel, and Santa Juliana (all from Minas Gerais State). These populations were clustered together at $17 \%$ disagreement. Six of them (populations 3 and 6 through 10 in Table I) were previously characterized as race 3 through differential varieties (Silva, 1997).

All random primers tested distinguished population 5 (Chapadão do Céu, GO - sample 2) from the others. OPA07 primer (Figure 2) yielded a similar pattern of DNA amplification products, with a clear marker of approximately $2.5 \mathrm{~kb}$ that was common to the majority of the populations that were characterized as race 3 through differential genotypes. The electrophoretic profile obtained with primer
OPA-10 detected slight variation within eight SCN populations from Minas Gerais (Figure 3), and six of them were characterized as race 3 through differential varieties.

\section{DISCUSSION}

In the dendrogram generated through the use of genetic distances (Figure 1), eight groups of SCN populations were formed from left to right at the $17 \%$ genetic distance level: I) Primavera do Leste, MT (race 1); II) Uberlândia, MG, through Santa Juliana, MG; III) Chapadão do Céu, GO (sample 1) and Chapadão do Sul, MS; IV) Água Clara, MS (race 9); V) Campo Verde, MT (race 2); VI) Romaria, MG; VII) Nova Ponte, MG, and VIII) Chapadão do Céu, GO (sample 2).

Cluster II included eight of the 10 populations that were collected in Minas Gerais State, and six of them were

Table I - Populations of Heterodera glycines from Brazil used in this study.

\begin{tabular}{|clc|}
\hline SCN Population & \multicolumn{1}{c}{ Site (State) } & Previously determined race \\
\hline 1 & Primavera do Leste - Mato Grosso (MT) & 1 \\
2 & Campo Verde - Mato Grosso (MT) & 2 \\
3 & Uberlândia - Minas Gerais (MG) & 3 \\
4 & Água Clara - Mato Grosso do Sul (MS) & 9 \\
5 & Chapadão do Céu - Goiás (GO) (sample 2) & - \\
6 & Pedrinópolis - Minas Gerais (MG) & 3 \\
7 & Monte Carmelo - Minas Gerais (MG) & 3 \\
8 & Coromandel - Minas Gerais (MG) & 3 \\
9 & Uberaba - Minas Gerais (MG) & 3 \\
10 & Santa Juliana - Minas Gerais (MG) & - \\
11 & Iraí de Minas - Minas Gerais (MG) (sample 1) & - \\
12 & Iraí de Minas - Minas Gerais (MG) (sample 2) & - \\
13 & Nova Ponte - Minas Gerais (MG) & - \\
14 & Romaria - Minas Gerais (MG) & - \\
15 & Chapadão do Céu - Goiás (GO) (sample 1) & - \\
16 & Chapadão do Sul - Mato Grosso do Sul (MS) & - \\
\hline
\end{tabular}

Table II - List of primers used in this study, range in size of DNA fragments $(\mathrm{kb})$, and number of monomorphic and polymorphic fragments.

\begin{tabular}{|c|c|c|c|c|}
\hline \multirow[t]{2}{*}{ Primer } & \multirow[t]{2}{*}{ Sequence $\left(5^{\prime} \rightarrow 3^{\prime}\right)$} & \multirow{2}{*}{$\begin{array}{l}\text { Range in size of DNA } \\
\text { fragments }(\mathrm{kb})\end{array}$} & \multicolumn{2}{|c|}{ Number of fragments } \\
\hline & & & Monomorphic & Polymorphic \\
\hline OPA-02 & TGC CGA GCT G & $0.39-1.25$ & 5 & 3 \\
\hline OPA-03 & AGT CAG CCA C & $0.38-1.60$ & 2 & 6 \\
\hline OPA-05 & AGG GGT CTT G & $1.50-3.10$ & - & 5 \\
\hline OPA-06 & GGT CCC TGA C & $1.20-1.60$ & - & 2 \\
\hline OPA-07 & GAA ACG GGT G & $1.20-5.20$ & 2 & 6 \\
\hline OPA-08 & GTG ACG TAG G & $0.89-1.80$ & 2 & 1 \\
\hline OPA-10 & GTG ATC GCA G & $1.80-5.40$ & - & 8 \\
\hline OPA-11 & CAA TCG COG T & $0.60-2.50$ & 3 & 1 \\
\hline OPA-13 & CAG CAC CCA C & $0.50-4.00$ & 6 & - \\
\hline OPA-17 & GAC CGC TTG T & $0.70-5.00$ & - & 8 \\
\hline OPA-18 & AGG TGA COG T & $1.10-1.60$ & - & 4 \\
\hline AT-O4 & AAT CGG CTG & $0.40-2.00$ & - & 4 \\
\hline Total & & - & 20 & 48 \\
\hline
\end{tabular}


Table III - Pairwise genetic distances as percent

disagreement among 16 populations of Heterodera glycines used in this study.

\begin{tabular}{|c|c|c|c|c|c|c|c|c|c|c|c|c|c|c|c|c|}
\hline $\begin{array}{c}\text { SCN } \\
\text { populations }\end{array}$ & 1 & 2 & 3 & 4 & 5 & 6 & 7 & 8 & 9 & 10 & 11 & 12 & 13 & 14 & 15 & 16 \\
\hline 1 & $\ldots$ & 22 & 16 & 25 & 41 & 18 & 18 & 24 & 19 & 22 & 18 & 21 & 28 & 26 & 22 & 19 \\
\hline 2 & & $\ldots$ & 26 & 32 & 37 & 25 & 28 & 28 & 26 & 29 & 28 & 31 & 26 & 19 & 29 & 18 \\
\hline 3 & & & $\ldots$ & 24 & 49 & 01 & 04 & 13 & 03 & 09 & 01 & 07 & 24 & 22 & 15 & 21 \\
\hline 4 & & & & $\ldots$ & 37 & 22 & 25 & 28 & 24 & 24 & 25 & 31 & 32 & 37 & 21 & 26 \\
\hline 5 & & & & & $\ldots$ & 47 & 47 & 50 & 49 & 46 & 47 & 56 & 31 & 38 & 43 & 37 \\
\hline 6 & & & & & & $\ldots$ & 03 & 12 & 01 & 07 & 03 & 09 & 22 & 21 & 13 & 19 \\
\hline 7 & & & & & & & $\ldots$ & 12 & 04 & 07 & 03 & 12 & 22 & 21 & 13 & 19 \\
\hline 8 & & & & & & & & $\ldots$ & 10 & 07 & 12 & 18 & 25 & 26 & 19 & 25 \\
\hline 9 & & & & & & & & & $\ldots$ & 09 & 04 & 10 & 24 & 22 & 15 & 21 \\
\hline 10 & & & & & & & & & & $\ldots$ & 07 & 13 & 24 & 25 & 18 & 24 \\
\hline 11 & & & & & & & & & & & $\ldots$ & 09 & 22 & 21 & 13 & 19 \\
\hline 12 & & & & & & & & & & & & $\ldots$ & 28 & 24 & 19 & 25 \\
\hline 13 & & & & & & & & & & & & & $\ldots$ & 22 & 32 & 32 \\
\hline 14 & & & & & & & & & & & & & & $\ldots$ & 25 & 19 \\
\hline 15 & & & & & & & & & & & & & & & $\ldots$ & 15 \\
\hline 16 & & & & & & & & & & & & & & & & $\ldots$ \\
\hline
\end{tabular}

1)-Primavera do Leste-MT (race 1); 2)-Campo Verde-MT (race 2); 3)-Uberlândia-MG (race 3); 4)-Água Clara-MS (race 9); 5)-Chapadão do Céu-GO (sample 2); 6)-Pedrinópolis-MG; 7)-Monte Carmelo-MG; 8)-Coromandel-MG; 9)-UberabaMG; 10)-Santa Juliana-MG; 11)-Iraí de Minas-MG (sample 1); 12)-Iraí de Minas-MG (sample 2); 13)-Nova Ponte-MG; 14)-Romaria-MG; 15)-Chapadão do Céu-GO (sample 1); 16)-Chapadão do Sul-MS.

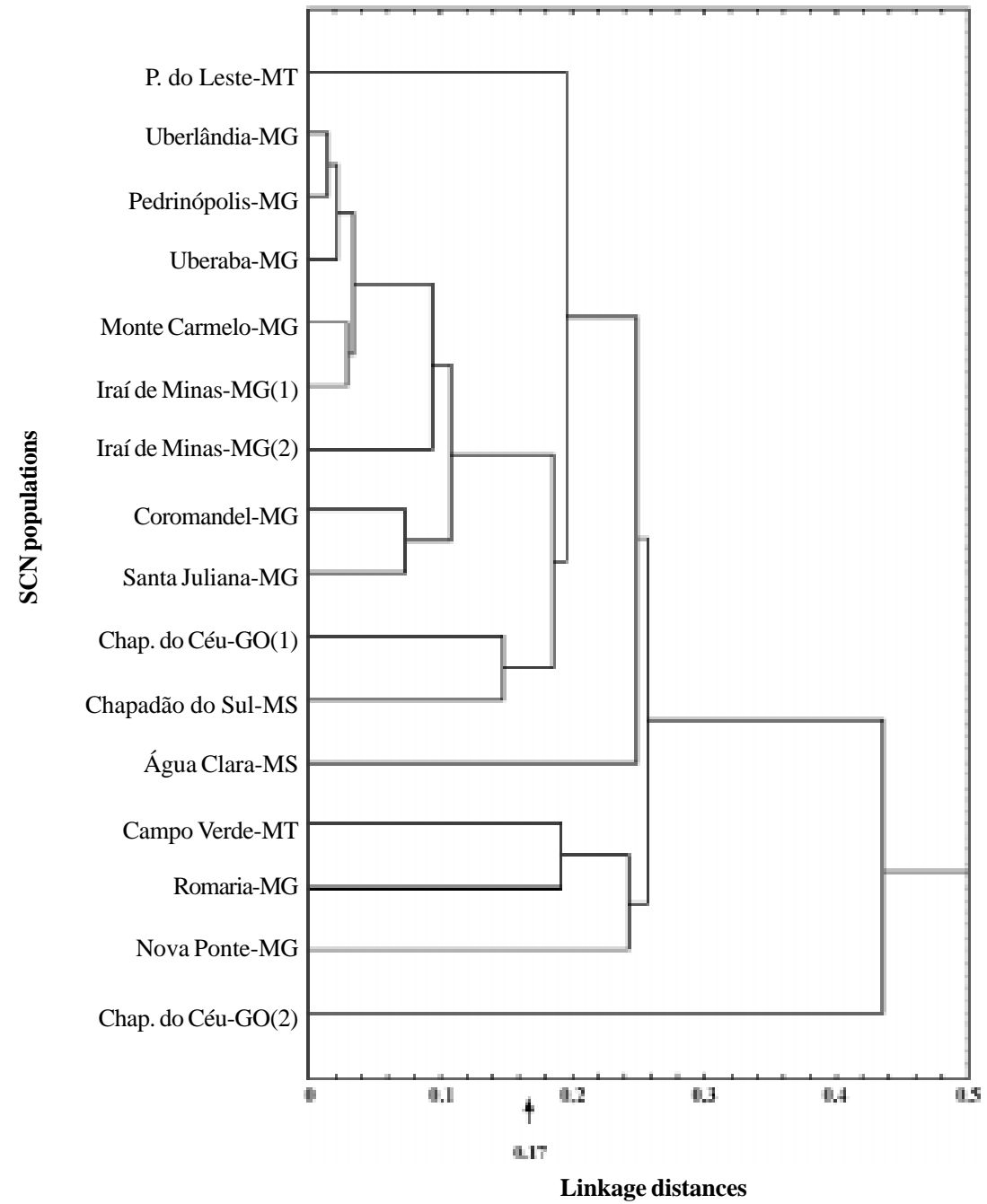

Figure 1 - UPGMA dendrogram generated with genetic distances as percent disagreement for 16 different populations of Heterodera glycines. These genetic distances were calculated with 68 RAPD markers obtained with 12 different random primers. 

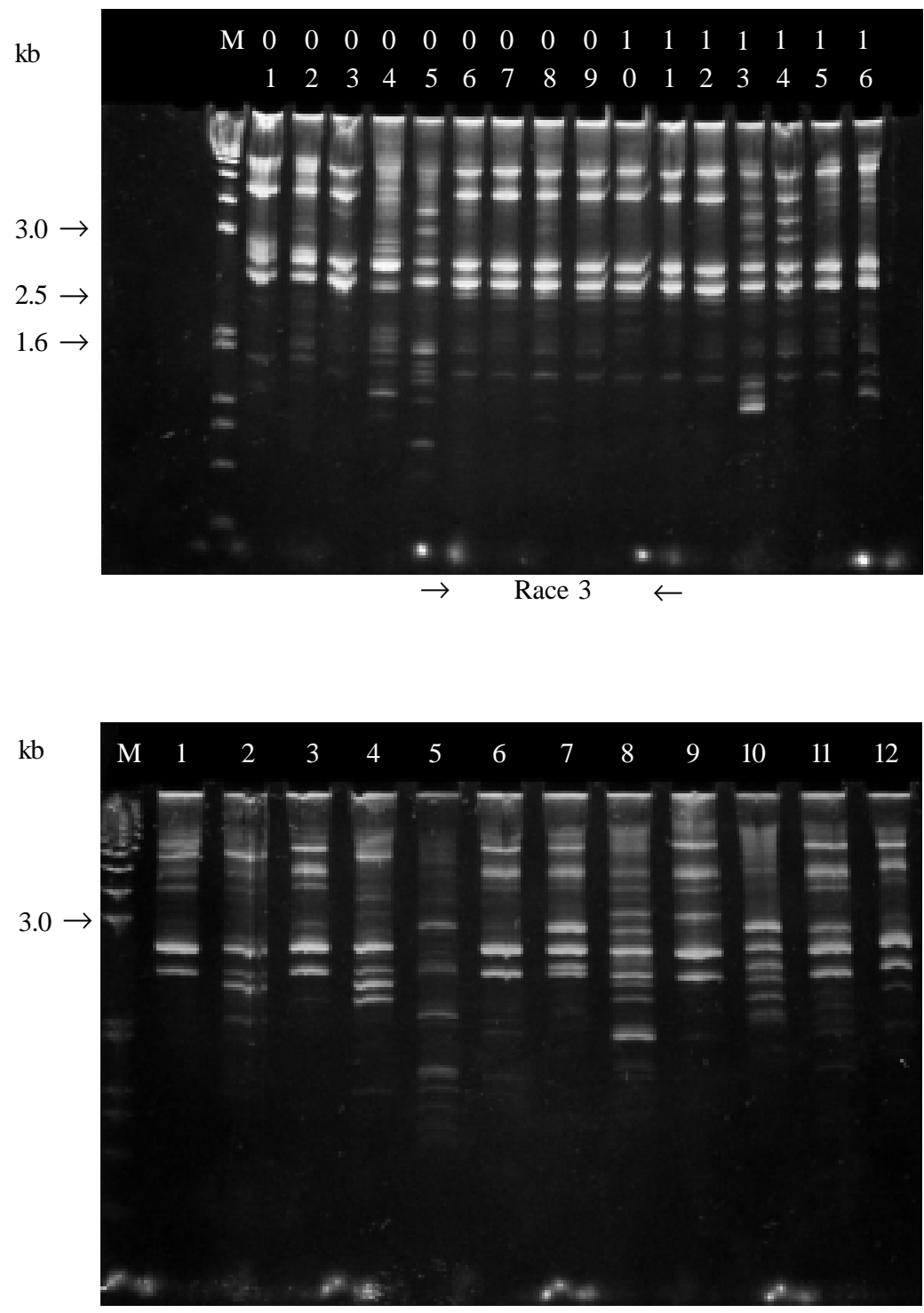

Figure 2 - Electrophoretic analysis of DNA amplification products from Heterodera glycines populations obtained on $8 \%$ polyacrylamide gel. Amplifications were performed with primer OPA-07. Lane M = Molecular size standard. Lanes 1 through 16 correspond to the amplification products of the 16 SCN populations, as identified in Table I.

Figure 3 - Electrophoretic analysis of DNA amplification products from Heterodera glycines populations obtained on $8 \%$ polyacrylamide gel. Amplifications were performed with primer OPA-10. Lane M = Molecular size standard. Lanes 1 through 12 correspond to the amplification products of the first $12 \mathrm{SCN}$ populations, as identified in Table I.

previously classified as race 3 (Table I). The two remaining SCN populations (Iraí de Minas, samples 1 and 2) have not been identified thus far through differential genotypes, but presented similar electrophoretic profiles with primer OPA-07 as compared with the profiles obtained for populations identified as race 3 .

The clustering at the $17 \%$ disagreement level revealed at least three important aspects: I) clear separation of the populations classified previously on the basis of differential varieties, as races 1,2,3 and 9. This result is fully consistent with the ones from direct analysis of RFLP carried out by Kalinski and Huettel (1988), who found differences among races 3, 4, and 5; II) the population of soybean cyst nematode from Chapadão do Céu, GO - sample 2 - was considerably different from all others, and III) eight of the 10 SCN populations from Minas Gerais had similar electrophoretic profiles (Figure 2), and were clustered together.
The difference between the Nova Ponte and Romaria nematode populations is obvious, especially when they are compared with others collected in Minas Gerais State. These two populations were exposed to temperatures above $36^{\circ} \mathrm{C}$ for nearly one year, and this could have caused an unfavorable selection pressure on the soybean cyst nematode. Slack and Hamblen (1961) demonstrated that soybean cyst nematode larvae failed to emerge from cysts incubated below $16^{\circ}$ or above $36^{\circ} \mathrm{C}$. However, research is needed to determine whether high temperature can increase variability in pathogen populations.

The electrophoretic profile obtained with OPA-07 primer (Figure 2) established a similar DNA amplification pattern for $\mathrm{SCN}$ populations characterized as race 3 through the host differential technique. This primer yielded a band of approximately $2.5 \mathrm{~kb}$ that appeared to be common to the majority of populations characterized as 
race 3. Therefore, RAPD markers could be a useful diagnostic tool to distinguish races of soybean cyst nematodes. However, more experiments are needed to determine if the variability within race 3 of the SCN is an indication of a new race, that would result in variable plant symptoms, suggesting nematode adaptation.

There was a slight variation within populations characterized as race 3 in the electrophoretic profile obtained with primer OPA-10 (Figure 3). This variability was consistent with that based on host differentials (Faghihi et al., 1986; Rao-Arelli et al., 1992; Aiba et al., 1995).

In conclusion, RAPD markers are useful for studying genetic variability among SCN populations and within races of this nematode. Variability within nematode races may indicate pathogen adaptation to environment and crop rotation. This variability could cause variable plant symptoms, as observed in genotypes used as host differentials. New RAPD markers would facilitate monitoring nematode population dynamics.

\section{RESUMO}

Heterodera glycines Ichinohe, o nematóide de cisto da soja ( $\mathrm{SCN}$ ), foi detectado no Brasil em 1.992 e desde então tem provocado perdas consideráveis à produtividade da soja brasileira. Populações de SCN apresentam grande diversidade genética, o que dificulta o manejo dessa cultura em áreas infestadas. Os objetivos desta pesquisa foram investigar a possível variação genética de dezesseis populações de SCN amostradas nas regiões Centro Oeste e Sudeste do Brasil, utilizando a técnica do RAPD (amplificação casualizada de DNA polimórfico), bem como estabelecer marcadores RAPD específicos para a raça 3 do SCN. Nossos resultados mostraram que os marcadores RAPD podem ser utilizados em estudos de variabilidade genética entre populações de SCN e dentro de raças deste nematóide, bem como podem ser usados no monitoramento de dinâmica populacional deste patógeno. O "primer" OPA-07 foi considerado satisfatório como marcador molecular para a raça 3 , enquanto a análise eletroforética dos fragmentos de DNA amplificados com a utilização do "primer" OPA-10 detectou ligeira variação nas populações de SCN identificadas como raça 3. A população do SCN oriunda de Chapadão do Céu, GO - amostra 2 - foi a geneticamente mais distante, quando comparada às demais usadas neste estudo.

\section{REFERENCES}

Aiba, S., Shimizu, K. and Mitsui, Y. (1995). Parasitic variation in populations of soybean cyst nematode multiplied from a single cyst. Res. Bull. Hokkaido N. Agric. Exp. Stn. 160: 75-83 (Abstract).

Anand, S.C., Sharma, S.B., Rao-Arelli, A.P. and Wrather, J.A. (1994). Variation in parasitic potential of Heterodera glycines populations. Crop Sci. 34: 1452-1454.

Arantes, N.E., Almeida, L.A., Kiihl, R.A.S. and Martins Filho, S. (1994). Resultados preliminares de trabalho sobre nematóide de cisto Heterodera glycines obtidos em Nova Ponte - MG. In: Programa Nacional de Apoio ao Controle e Prevenção do Nematóide de Cisto da Soja: Proposta para Implementação. MAARA-SDA/EMBRAPA/IICA/ABRASEM/ COBRAFI, Brasília pp. 34 (Resumo).

Assigbetse, K.B., Fernandez, D., Dubois, M.P. and Geiger, J.P. (1994). Differentiation of Fusarium oxysporum f. sp. vasinfectum races on cotton by random amplified polymorphic DNA (RAPD) analysis. Phytopathology 84: 622-626.

Baldwin, J.G. and Mundo-Ocampo, M. (1991). Heteroderinae, cyst- and noncyst-forming nematodes. In: Manual of Agricultural Nematology (Nickle, W.R., ed.). Marcel Dekker, New York, pp. 275-362.

Castagnone-Sereno, P. (1992). Evolution of molecular biology techniques in nematode nuclear DNA characterization: Results and prospects for identification and phylogeny. In: XVI Congresso Brasileiro de Nematologia, 1.992, Sociedade Brasileira Nematologia, Lavras, MG, pp. 8-9.

Caswell-Chen, E.P., Williamson, V.M. and WU, F.F. (1992). Random amplified polymorphic DNA analysis of Heterodera cruciferae and $H$. schachtii populations. J. Nematol. 24: 343-351.

Curran, J., Mcclure, M.A. and Webster, J.M. (1986). Genotypic differentiation of Meloidogyne populations by detection of restriction fragment length difference in total DNA. J. Nematol. 18: 83-86.

Demeke, T., Adams, R.P. and Chibbar, R. (1992). Potential taxonomic use of random amplified polymorphic DNA (RAPD): a case study in Brassica. Theor. Appl. Genet. 84: 990-994.

EMBRAPA - Centro Nacional de Pesquisa de Soja (1996). Recomendações Técnicas para a Cultura da Soja na Região Central do Brasil 1996/ 97. Londrina - PR, Embrapa-soja. Documentos, 96, pp. 164.

Faghihi, J., Ferris, J.M. and Ferris, V.R. (1986). Heterodera glycines in Indiana: I. Reproduction of geographical isolates on soybean differentials. J. Nematol. 18: 169-172.

Folkertsma, R.T., Van Der Voort, J.N.A.M.R., Van Gent-Pelzer, M.P.E., Groot, K.E., Van Den Bos, W.J., Schots, A., Bakker, J. and Gommers, F.J. (1994). Inter- and intraspecific variation between populations of Globodera rostochiensis and G. pallida revealed by random amplified polymorphic DNA. Phytopathology 84: 807-811.

Golden, A.M., Epps, J.M., Riggs, R.D., Duclos, L.A., Fox, J.A. and Bernard, R.L. (1970). Terminology and identity of infraspecific forms of the soybean cyst nematode (Heterodera glycines). Plant Dis. Rep. 54: 544546.

Griffith, T.W., Koehler, N.J., Coker, S.G. and Riggs, R.D. (1982). Race comparisons of Heterodera glycines using crossed immunoelectrophoresis. J. Nematol. 14: 598-599.

Guirao, P., Moya, A. and Cenis, J.L. (1995). Optimal use of random amplified polymorphic DNA in estimating the genetic relationship of four major Meloidogyne spp. Phytopathology 85: 547-551.

Kalinski, A. and Huettel, R.N. (1988). DNA restriction fragment length polymorphism in races of the soybean cyst nematode, Heterodera glycines. J. Nematol. 20: 532-538.

Mackill, D.J. (1995). Classifying japonica rice cultivars with RAPD markers. Crop Sci 35: 889-894.

Mendes, M.L. (1986). Análise comparativa de alguns métodos de extração de nematóides do solo. Master's thesis, Viçosa, MG, Brasil.

Mendes, M.L. and Dickson, D.W. (1993). Detection of Heterodera glycines on soybean in Brazil. Plant Dis. 77: 499-500.

Noel, G.R., Mendes, M.L. and Machado, C.C. (1994). Distribution of Heterodera glycines races in Brazil. Nematropica 24: 63-68.

Orozco-Castilho, C., Chalmers, K.J., Powell, W. and Waugh, R. (1996). RAPD and organelle specific PCR re-affirms taxonomic relationships within the genus Coffea. Plant Cell Rep. 15: 337-341.

Pozdol, R.F. and Noel, G.R. (1984). Comparative electrophoretic analyses of soluble proteins from Heterodera glycines races 1-4 and three other Heterodera species. J. Nematol. 16: 332-340.

Rao-Arelli, A.P., Wrather, J.A. and Anand, S.C. (1992). Genetic diversity among isolates of Heterodera glycines and sources of resistance in soybeans. Plant Dis. 76: 894-896.

Riggs, R.D. and Schmitt, D.P. (1988). Complete characterization of the race scheme for Heterodera glycines. J. Nematol. 20: 392-395.

Rossi, C.E., Miranda, M.A.C., Araújo, A.C.M. and Adde, M.F.V. (1994). Reação de genótipos e cultivares de soja a Heterodera glycines, raça 3. Fitopatol. Bras. 19 (Suppl.): 285 (Resumo).

Sambrook, J., Fritsch, E.F. and Maniatis, T. (1989). Molecular Cloning - A Laboratory Manual. 2nd edn. Vol. 3. Cold Spring Harbor Laboratory Press, Cold Spring Habor.

Silva, A.T. (1997). Estudo da variabilidade genética do nematóide de cisto da soja (Heterodera glycines Ichinohe, 1952) por meio de marcadores RAPD e hospedeiros diferenciadores. Master's thesis, Universidade Federal 
de Uberlândia, Uberlândia, MG, Brasil.

Skroch, P., Tivang, J. and Nienhuis, J. (1992). Analysis of genetic relationships using RAPD marker data. Proceedings of the Symposium - Applications of RAPD Technology to Plant Breeding, Minneapolis, MN, USA, pp. 26-30.

Slack, D.A. and Hamblen, M.L. (1961). The effect of various factors on larval emergence from cysts of Heterodera glycines. Phytopathology 51:350-355.

Vasconcelos, M.J.V., Abdelnoor, R.V., Almeida, A.M.R., Mendes, M.L., Barros, E.G. and Moreira, M.A. (1994). Estudo da variabilidade genética de cinco isolados de nematóide do cisto, Heterodera glycines Ichinohe. Fitopatol. Bras. 19 (Suppl.) : 324 (Resumo).

Wain, A.L. and Silva, J.F.V. (1996). Levantamento de ocorrência de raças de
Heterodera glycines no Brasil. XVIII Reunião de Pesquisa de Soja da Região Central do Brasil, Uberlândia, MG, Brasil, pp. 446.

Welsh, J. and Mcclelland, M. (1990). Fingerprinting genomes using PCR with arbitrary primers. Nucleic Acids Res. 18: 7213-7218.

Williams, J.G.K., Kubelik, A.R., Livak, K.J., Rafalski, J.A. and Tingey, S.V. (1990). DNA polymorphisms amplified by arbitrary primers are useful as genetic markers. Nucleic Acids Res. 18: 6531-6535.

Woo, S.L., Zoina, A., Del Sorbo, G., Lorito, M., Nanni, B., Scala, F. and Noviello, C. (1996). Characterization of Fusarium oxysporium f. sp phaseoli by pathogenic races, VCGs, RFLPs, and RAPD. Phytopathology 86: 966-973.

(Received January 26, 2000) 
